\title{
Cattle distribution patterns and vegetation use in mountain riparian areas
}

\author{
CORY T. PARSONS, PATRICK A. MOMONT, TIMOTHY DELCURTO, MICHAEL MCINNIS, AND MARNI L. \\ PORATH
}

Authors are Assistant Professor, Department of Animal Science, Oregon State University, Prineville, Oregon 97754; Associate Professor, Department of Animal and Veterinary Science, Caldwell Research and Extension Center, University of Idaho, Caldwell, Ida. 83605; Associate Professor, Department of Animal Science, Eastern Oregon Agricultural Research Center, Oregon State University, Union, Ore. 97883; Associate Professor, Rangeland Resources Department, Oregon State University Agricultural Program, La Grande, Ore. 97850; Assistant Professor, Department of Rangeland Resources, Oregon State University, Corvallis, Ore. 97331. At time of the research, the senior author was Graduate Student Research Assistant, Animal and Veterinary Science Department, University of Idaho, Moscow, Ida. 83844.

Abstract

To quantify the effects of season of use on beef cattle distribution relative to the riparian area, $52 \mathrm{cow} / \mathrm{calf}$ pairs were used to evaluate 1) early summer grazing (mid-June to mid-July), and 2) late summer grazing (mid-August to mid-September) during the summers of 1998 and 1999. Within a block, cow/calf pairs used during early summer were also used during late summer grazing periods. Pastures were stocked to achieve $50 \%$ utilization of herbaceous vegetation after a 28 -day grazing trial. Livestock location and ambient air temperature were recorded hourly during two, 4-day periods in each season of use. Locations were transcribed to a geographical information system for the study area. Ocular vegetation utilization estimates, forage quality, and fecal deposits within 1-m of the stream were recorded post-grazing. During early summer, cattle were further from the stream $(P<$ 0.01) than late summer, averaging 161 and $99-\mathrm{m}$, respectively. Cows were observed closer $(P<0.01)$ to the stream when ambient air temperatures were higher. Fecal deposits within 1-m of the stream were similar $(P=0.13)$ following early and late summer grazing. Forage quality varied $(P<0.01)$ between seasons, with early summer forages having lower dry matter, greater crude protein, lower fiber, and greater in situ dry matter disappearance compared with late summer forages. Utilization of riparian vegetation was lower and use of upland vegetation greater during early summer than late summer $(P<0.05)$. In summary, season of use affected cattle distribution relative to the riparian area, with late summer pastures having more concentrated use of riparian vegetation.

Key Words: Beef cattle, distribution patterns, riparian areas, season of use, vegetation utilization

Ecological degradation of riparian ecosystems is one of the greatest contemporary concerns for livestock grazing on western rangelands. Excessive use of riparian areas by livestock can result in removal of woody vegetation, over utilization of streamside vegetation, soil compaction, increased soil erosion, reduced water

Research was partially funded by a USDA Sustainable, Agriculture, Research, and Education (SARE) grant as well as Oregon State University and University of Idaho Agriculture Experiment Station IAES \#00A06.

Manuscript accepted 26 Sept. 02.
Resumen

Durante los veranos de 1998 y 1999 se utilizaron 52 pares de vaca-becerro para cuantificar los efectos de la época de uso en la distribución del ganado en un área ribereña y para ello se evaluaron los siguientes tratamientos: 1) apacentamiento a inicios de verano (mediados de junio a mediados de julio) y 2) apacentamiento a finales de verano (mediados de Agosto a mediados de Septiembre). Dentro de un bloque, los pares de vaca-becerro utilizados a inicios de verano también se usaron en los periodos de fines de verano. Los potreros se cargaron para alcanzar una utilización de $50 \%$ de la vegetación herbácea en un periodo experimental de 28 días. La ubicación del ganado y la temperatura ambiente se registraron cada hora durante dos periodos de 4 días en cada época de uso. Las ubicaciones se introdujeron a un sistema de información geográfica para el área de estudio. Después del periodo de apacentamiento se registraron estimaciones oculares de la utilización de la vegetación, calidad del forraje y depósitos fecales dentro de un área de 1 metro de la corriente. A inicio del verano el ganado se alejo mas de la corriente que a fines del verano (P $<0.01$ ) promediando 161 y 99 m respectivamente. Cuando las temperatura ambiente era mas alta se observaron las vacas significativamente $(P<0.01)$ mas cerca de la corriente. Los depósitos fecales dentro de la franja de $1 \mathrm{~m}$ de la corriente fueron similares $(P=0.13)$ en ambas épocas de apacentamiento. La calidad de forraje vario $(P<0.01)$ entre épocas, a inicios de verano el forraje tenia menos materia seca, mayor proteína cruda, menos fibra y una mayor tasa de desaparición in situ de la materia seca en comparación con el forraje de fines de verano. A inicios de verano el uso de la vegetación ribereña fue mas bajo y el uso de la vegetación alejada del área ribereña fue mayor $(P<0.05)$ en comparación con la época de fines de verano. En resumen, la época de uso afecto la distribución del ganado en las áreas ribereñas, y es a fines de verano cuando se concentra el uso de la vegetación ribereña.

quality, and streambank degradation (Buckhouse and Gifford 1976, Thomas et al. 1979). Cattle are attracted to riparian areas by environmental and nutritional factors and may utilize riparian vegetation disproportionately more than adjacent uplands (Gillen et al. 1984, Howery et al. 1996).

Livestock grazing management in riparian areas is one of the most pervasive issues facing rangeland managers in the western 


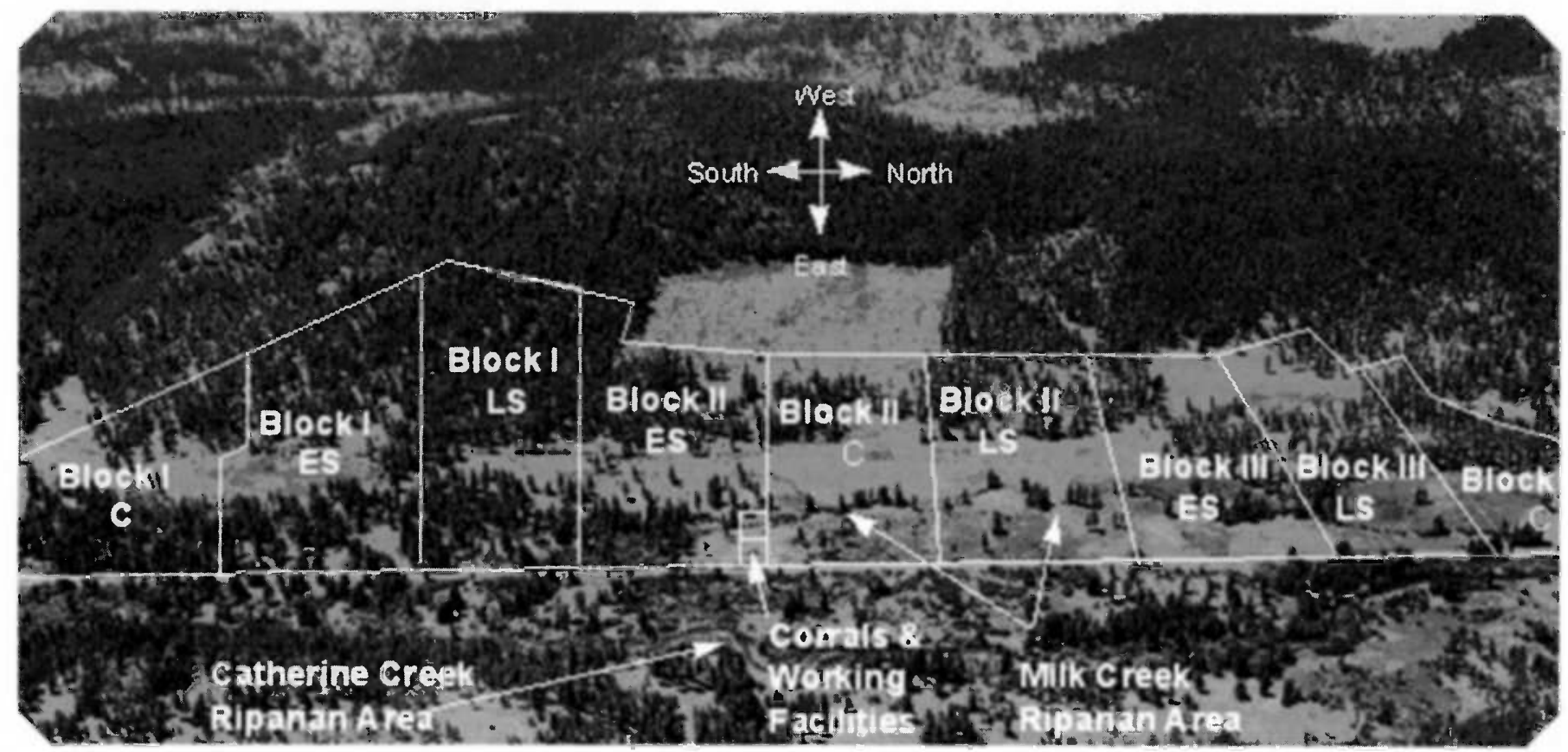

Fig. 1. Portion of Oregon State University's Hall Ranch utilized for the research project. Six pastures, 10 to 15 hectares in size were utilized in a replicated design evaluating 2 seasons of use over a 2-year study period. All pastures have riparian stream, riparian meadow, and adjacent uplands. Treatments included early summer grazing (ES), late summer grazing (LS), and a control (C).The three control pastures (one per block) were not grazed or used during this study.

U.S. (Leonard et al. 1997). Although riparian areas constitute only about $8 \%$ of the total public land acreage, and less than $1 \%$ of the public land in many of the more arid western states (USDI 1995), most grazing allotments contain some riparian acreage. Federal laws such as the Threatened and Endangered Species Act (1973), and the Federal Water Pollution Control Act (1972) are making it increasingly important for rangeland managers, to identify and implement grazing management strategies that maintain or improve the sustainability of riparian ecosystems. One such livestock management strategy may be grazing riparian areas in the spring when key forage species are vegetative, forage quality is high, and ambient air temperatures are low. Currently, the efficacy of this strategy for increasing the uniformity of grazing has not been quantitatively evaluated.

The objective of this research project was to provide a replicated, quantitative assessment of the effects of season of use (early versus late summer), on cattle grazing and vegetation utilization patterns within riparian areas and adjacent uplands in northeastern Oregon. Our hypothesis was that livestock grazing distribution and forage utilization patterns would be more uniform during early summer (Elmore and Kauffman 1994), and riparian areas would receive disproportionately more use than uplands during late summer (Gillen et al. 1985).

\section{Materials and Methods}

\section{Location}

This study was conducted on 109 ha of the Eastern Oregon Agricultural Research Center's Hall Ranch located in the foothills of the Wallowa Mountains in northeastern Oregon (latitude $45^{\circ} 7^{\prime} 48^{\prime \prime}$ $\mathrm{N}$, longitude $117^{\circ} 42^{\prime} 32^{\prime \prime} \mathrm{W}$ (Fig. 1)). Study site elevation is approximately $1,015-\mathrm{m}$, with annual precipitation averaging $350-\mathrm{mm}$. Most of the precipitation comes between October and June, which

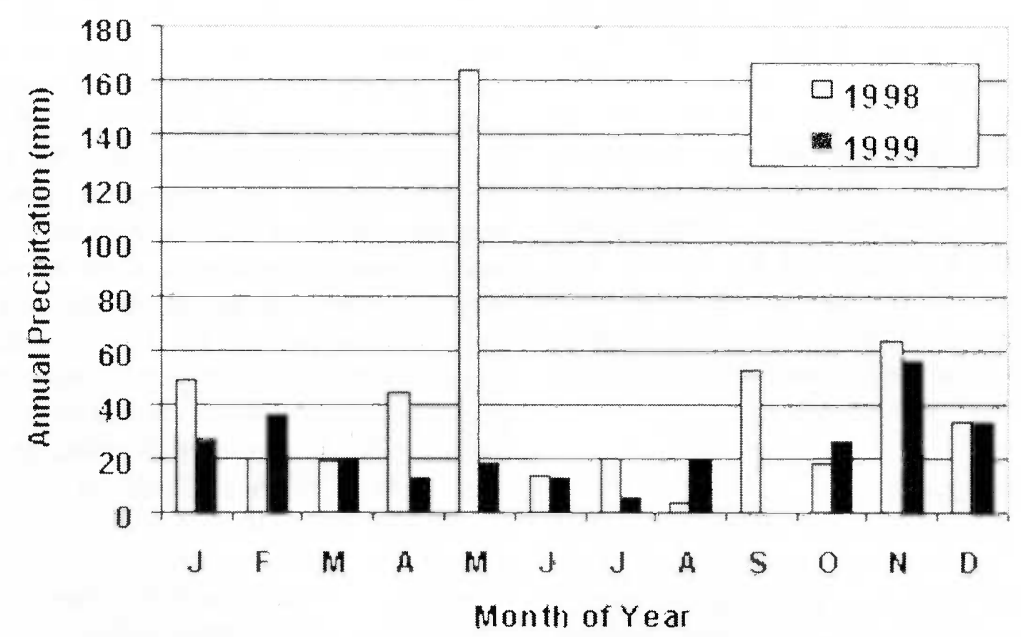

Fig. 2. Monthly precipitation during the study years of 1998 and 1999, Data were collected from the Eastern Oregon Agriculture Research Center Weather Station, Union, Ore. results in dry summers and limited poten tial for vegetative re-growth during July through September.

The study site consisted of riparian meadows and adjacent uplands bordering Milk Creek, a tributary of Catherine Creek in the Grande Ronde River watershed. The site was cross-fenced with electric fence into nine, 10-15 ha pastures (Fig. 1). Each pasture contained about a $260-\mathrm{m}$ reach of Milk Creek. Within each pasture, vegetation was classified into 4 vegetation types: gravel bar, riparian grass, riparian sedge/rush, and upland. 
Annual amounts of precipitation (Fig. 2) varied between years with 1998 receiving above normal precipitation, $(500 \mathrm{~mm})$, and 1999 receiving below normal precipitation, (264 mm).

\section{Riparian Vegetation}

Green line vegetation was that vegetation located immediately on the stream banks edge. Gravel bar vegetation types were located within the riparian area and appeared to be remnants of past stream channels. This vegetation type consisted of mostly cheatgrass (Bromus tectorum L.), and Canada bluegrass (Poa comressa L.).

Riparian vegetation types were located within the floodplain and currently, or (had) in the recent past, been influenced by water from Milk Creek. Riparian grass vegetation consisted of greater than 50 percent grass by weight (Porath et al. 2002). Riparian grass vegetation types consisted of Kentucky bluegrass (Poa pratensis L.), brome (Bromus spp.), meadow foxtail (Alopecurus pratensis L.), timothy (Phleum pratense L.), rushes (Juncus spp. L.), sedges (Carex spp. L.), and a variety of forbs. Riparian sedge/rush vegetation types were located within the riparian grass communities but were distinguished by greater than $50 \%$ sedges and (or) rushes by weight (Porath et al. 2002). The overstory of woody species bordering Milk Creek in the riparian area included hawthorn (Crataegus douglasii Lindl.), ponderosa pine (Pinus ponderosa Dougl.), snowberry (Symphoricarpus albus L.), black cottonwood (Populus trichocarpa T. \& G.), and rose (Rosa gymnocarpa Nutt.).

\section{Upland Vegetation}

Upland vegetation types consisted of grasses including timothy, orchardgrass (Dactylus glomerata L.), needlegrass (Stipa spp. L.), brome, Idaho fescue (Festuca idahoensis Elmer), Kentucky bluegrass, pinegrass (Calamagrostis rubescens Buckl.) elk sedge (Carex geyeri Boott), a variety of forbs, and patches of shrubs including snowberry, spirea (Spirea splendens Baumann ex K. Koch), and ceanothus (Ceanothus spp. L.). Most of the upland sites had an overstory of ponderosa pine, though some areas were open, lacking a woody overstory.

\section{Pasture Design}

Nine pastures were stratified into 3 blocks based on vegetation type. Two treatments were randomly assigned to pastures within each block: 1) early summer grazing (mid-June to mid-July), and 2) late summer (mid-August to mid-September)
(Fig. 1). Each pasture within a block had similar proportions of the 4 vegetation types, with all cows having equal access to all portions of their assigned pasture.

\section{Cattle}

Fifty-two crossbred (Hereford x Angus) cow/calf pairs were randomly assigned to 1 of 3 blocks season of use year $^{-1}$. Cows used during the early summer trial were also used in the late summer grazing trial. In 1998, cows were all 2-year old primiparous heifers. In 1999, 49 cows were 2year old primiparous heifers and 3 cows were 3 years old. All cows used in this study had previous exposure to similar grazing areas as yearling heifers. Cows averaged $420-\mathrm{kg}$ at the beginning of the trial. Based on dry matter (DM) production estimates from previous years (Porath et al. 2002), pastures were stocked to achieve $50 \%$ relative herbaceous vegetation utilization (Frost et al. 1994) after 28days of grazing, with resulting stocking density of $1.7 \mathrm{AU} / \mathrm{ha}$.

\section{Livestock Distribution and Behavior}

Visual livestock observations and vibracorders were used to monitor hourly livestock distribution and grazing behavior patterns. Vibracorders were used to measure grazing times during each season of use and were placed on 6 randomly selected cows block ${ }^{-1}$ observation period ${ }^{-1}$ year $^{-1}$ for a total of 72 total vibracorder recordings. Vibracorder charts were read as minute's hour ${ }^{-1}$ and hours day ${ }^{-1}$ spent grazing during each season of use.

Visual observations during daylight hours (0600 to 1900 hours) were used to monitor cow location and activity throughout the day. Visual observations were collected during the second and third week of each season of use and were made hourly, for a total of 14 observations cow $^{-1}$ day $^{-1}$ pasture ${ }^{-1}$. The number of daily observations averaged 252 early summer and 242 late summer in each pasture for a total of 23,744 individual livestock visual observations. Cow locations were recorded on aerial photos at each observation period by 3 observers, 1 observer block ${ }^{-1}$. Large numbers were painted on both sides of each cow to facilitate individual cow identification. At each hourly observation, ambient air temperatures were recorded $(n=224)$. Livestock activities, (grazing, loafing/resting or drinking) were also recorded hourly during the visual observation period.

\section{Vegetation Utilization and Stubble Height}

Following procedures described by Pechanec and Pickard (1937), relative herbaceous vegetation utilization was measured at the end of each season of use, immediately following cattle removal. Vegetation utilization was ocularly estimated within $0.25-\mathrm{m}^{2}$ frames every $7.5-\mathrm{m}$ beginning at Milk Creek in perpendicular directions on each of 6 equally spaced transects in each pasture, with a mean of 387 ocular utilization estimates collected per pasture. At each observation point a utilization class was assigned, $(0=0$ percent utilization, $1=1$ to 25 percent utilization, $2=26$ to 50 percent utilization, $3=$ 51 to 75 percent utilization, and $4=76$ to 100 percent utilization), remaining herbaceous stubble height measured and vegetation type recorded. The remaining herbaceous stubble height was measured by placing a ruler at the furthest edge of the $0.25 \mathrm{~m}^{2}$ frame and measuring the height of the remaining forage to the nearest $\mathrm{cm}$.

Given the complexity of measuring utilization (measuring what is no longer there), training exercises were conducted prior to each ocular utilization period with all 5 utilization classifications being equally represented during the training. Following a training class, each of 6 observers independently visually appraised ten, $0.25-\mathrm{m}^{2}$ clip plots, and assigned their estimate of utilization. These plots had previously been clipped and the removed vegetation weighed. After ocular estimates were taken the remaining standing vegetation was clipped to within 2-cm of the ground and weighed. The formula for determining actual utilization class was:
Percent Utilization $=$ initial clipped weight X 100 (initial clipped weight + final clipped weight)

Observer estimates were then compared with actual utilization. Out of 156 total training estimates, only 1 was further than 1 utilization category from the actual. Observer bias was adjusted using the following regression equation which regressed estimated utilization against actual utilization: $\mathrm{Y}=0.77 \mathrm{x}+0.42$ with $\mathrm{r}^{2}$ $=0.64$, and $\mathrm{P}<0.01$. The $\mathrm{Y}$ variable in the above equation is actual utilization and the $\mathrm{X}$ variable is estimated utilization. A utilization score of 1 corresponded to 13 percent utilization (halfway between 1 and 25 percent utilization) and a utilization score of 2 corresponded to $38 \%, 3$ corresponded to $63 \%$ utilization, and 4 corresponded to $88 \%$ utilization. The regression equation 
used to correct visual scores $(0,1,2,3$, and 4) to estimated utilization percent was $Y=22.6 x-4.8$ with $r^{2}=0.83$, with the $Y$ variable being actual utilization score and the $\mathrm{X}$ variable being the estimated utilization score.

\section{Fecal Deposits}

Buckhouse and Gifford (1976) reported that a 1-month-old fecal deposit within 1$m$ of a stream significantly increased chances of impacting water quality following a high intensity simulated rainstorm, compared to fecal deposits beyond 1-m of a stream. It was easy to differentiate fresh from old feces because these pastures were grazed only during the 28-day trials each year. Based on this information, fresh fecal deposits located within 1-m of the stream's edge were counted on both sides of the stream in each pasture at the end of each grazing season.

\section{Precipitation}

Daily precipitation data were collected at the Eastern Oregon Agriculture Research Center's weather station (Union, Oregon) during the 2-year grazing study (Fig. 2).

\section{Forage Nutrient Composition}

At the end of the third week of each season of use, 20 randomly clipped plots were obtained from each grazed pasture. Ten, $0.25-\mathrm{m}^{2}$ plots were randomly collected from each riparian area and 10, 0.25- $\mathrm{m}^{2}$ plots were randomly clipped from each upland area. Samples were dried at $60^{\circ} \mathrm{C}$ for 48 hours and composited according to vegetation type (riparian or upland) within each pasture. Composited samples were ground to pass a 1-mm screen in a Wiley mill and analyzed for DM, Kjeldahl nitrogen / crude protein (CP; AOAC 1990), acid detergent fiber (ADF; AOAC 1990 as modified by Komarek and Sirios 1993), neutral detergent fiber (NDF; Van Soest et al. 1991 as modified by Komarek 1993), lignin, and in situ dry matter disappearance (ISDMD).

\section{Statistical Analysis}

Time series data (time within day observations) were analyzed as a randomized complete block-repeated measures design using the GLM procedure of SAS (1990). Block was treated as the random variable in all GLM procedures, with pasture being the experimental unit and season of use and year being factors within the model. Main effects were delineated using season of use by block as the whole plot error term. Time within day was considered the repeated variable. Interactions were tested using residual error (block interactions). Non-time series data (utilization, stubble height, fecal deposits, and precipitation) were analyzed as a randomized complete block design. This study was replicated over 2 years, 1998 and 1999. Treatment differences were delineated for all analysis using LSD procedures of SAS $(\mathrm{P}<0.05)$. All percentage data were analyzed using the proc GLM procedures of SAS, and a normal probability plot was run for block, treatment and time and was determined to be normally distributed, thus no transformations were needed. In addition, ambient air temperature was regressed against livestock distance from the stream using standard linear regression techniques to describe the relationship of ambient air temperature to diurnal livestock distribution patterns.

\section{Results and Discussion}

\section{Livestock Distribution and \\ Behavior}

Season of use affected livestock distribution patterns throughout the study. During early summer, cattle were consistently observed further from the stream at any given hour $(\mathrm{P}<0.01)$ than during late summer, averaging 161 and $99-\mathrm{m}$ respectively (Fig. 3). Cattle expressed diurnal distribution patterns in both early summer and late summer $(\mathrm{P}<0.01$; Fig. 3), with cattle being furthest away from the stream in the early morning, and gradually moving closer to the riparian area as the day progressed.

Cows were observed closer to the stream when ambient air temperatures were higher (Figs. 3 and 4). Ambient air temperatures were highly correlated with livestock distances from the stream $\left(\mathrm{r}^{2}=\right.$ 0.79 and 0.90 early summer and late summer, respectively; $\mathrm{P}<0.01)$. Ambient daytime air temperatures may have affected $(\mathrm{P}<0.01)$ distribution patterns (Fig. 3) and grazing times (Fig. 5) of cows.

During early summer, cattle visited riparian areas during late morning hours, then either returned to the uplands, or remained around the riparian area during the heat of the day, later returning to the uplands around late-afternoon (Fig. 3). During late summer, cattle began the day away from the stream, but quickly moved closer to the riparian area during the morning hours, occupied the shady areas of the riparian area during the heat of the day, and gradually returned to the uplands around late afternoon (Fig. 3).

Vibracorder data revealed that season of use affected grazing activity of cattle $(\mathrm{P}<$ 0.01; Fig. 5). Cattle had distinct trimodal daily grazing patterns during both seasons of use, exhibiting definite peak grazing times during the morning, mid-day and evening. Although livestock grazing patterns exhibited a season of use $\mathrm{x}$ time of day interaction $(P<0.01)$, total daily grazing times did not differ between seasons $(P=0.64)$. Cattle grazed on average 584 minutes day $^{-1}$ during the early summer, and 574 minutes day ${ }^{-1}$ during the late sum-

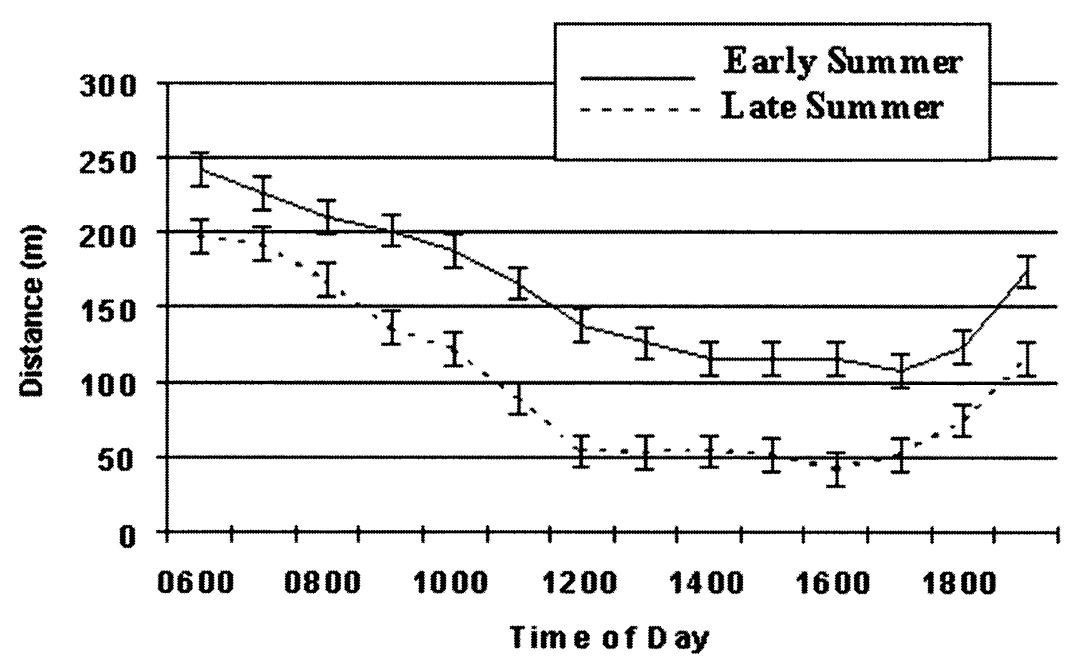

Fig. 3. Mean distance that cows were observed from the stream at hourly daylight intervals during early and late summer. Values are averaged over 1998 and 1999. Mean distances for early and late summer differed $(p<0.01)$ at all observed time periods. Bars on each value indicate standard errors. $N=\mathbf{2 3 , 7 4 4}$ cow observations. 


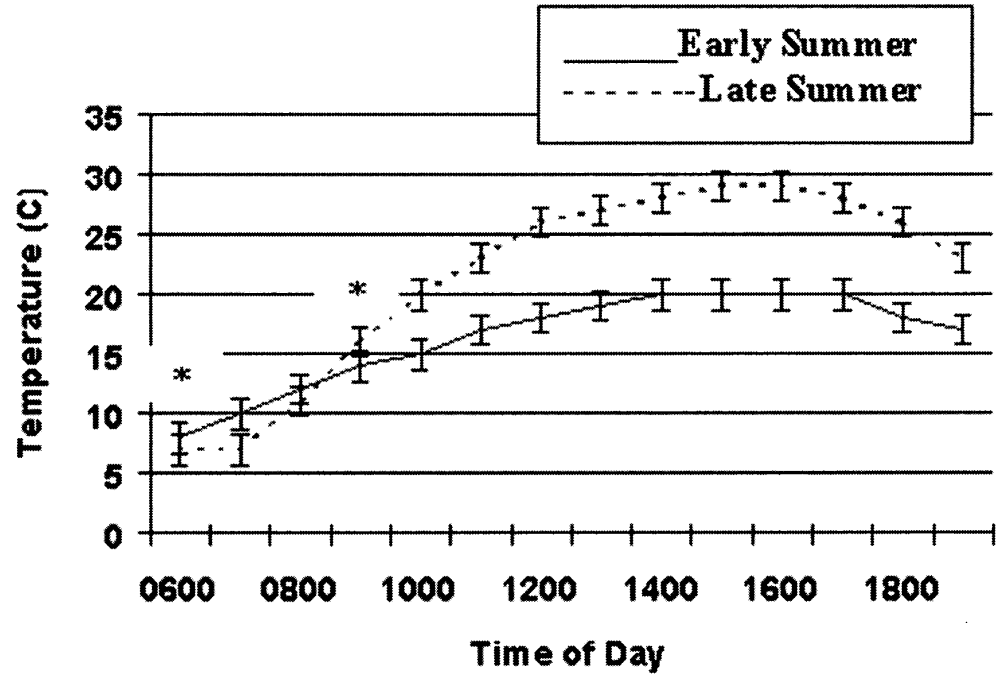

Fig. 4. Hourly ambient daylight temperatures during early and late summer. Values are averaged over 1998 and 1999. Values without an asterisk differ $(p<0.01)$. Bars indicate standard errors. $\mathbf{N}=\mathbf{2 2 4}$ temperature recordings.

mer. However, cows grazed more $(\mathrm{P}<$ 0.01 ), from $0100-0300,0700-0900,1300$ 1400 , and 1800-2000 hours during late summer than during early summer, and cows grazed less $(\mathrm{P}<0.01)$ from 0400 $0600,1000-1200$, and 1500-1600 hours during late summer than during early summer (Fig. 5). This seasonal difference in daily grazing activity is likely due to a difference in daylight hours coupled with a greater range of ambient air temperatures from morning until night in late summer.

Observational data showed that daylight cow activity, (grazing, loafing/resting, or

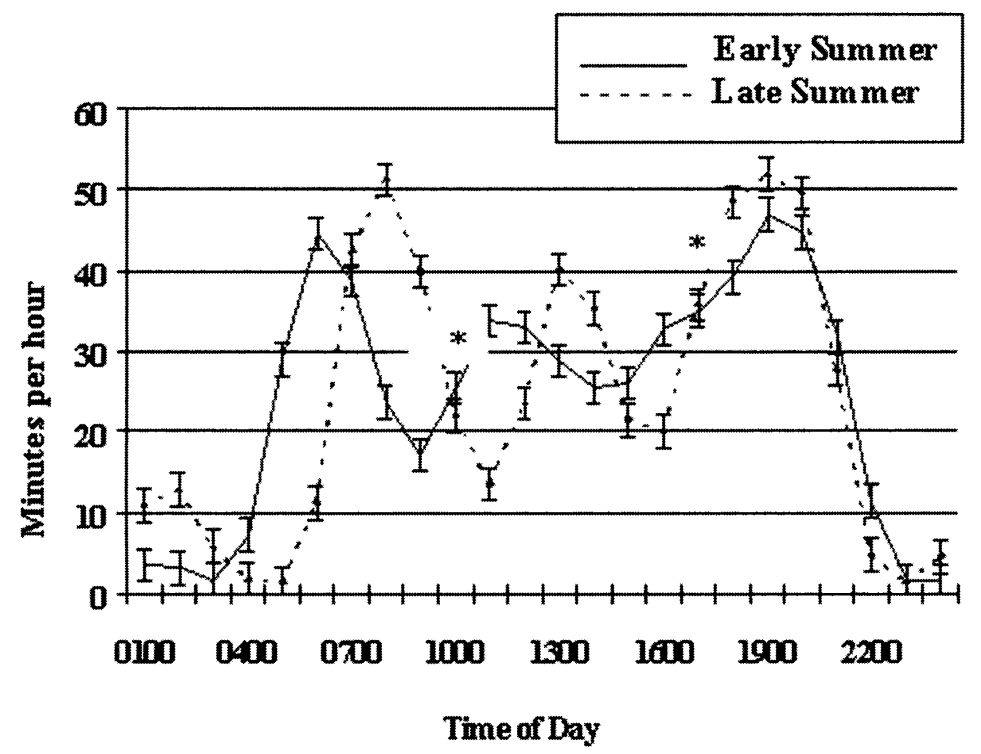

Fig.. 5. Minutes per hour spent grazing during early and late summer. Values are averaged over 1998 and 1999. Sunrise for early and late summer occurred at 0500 and 0600 hours, respectively, with sunset occurring at 2100 and 1900 hours, respectively. Values without an asterisk differ $(\mathrm{P}<\mathbf{0 . 0 1})$. Bars indicate standard errors. $\mathrm{N}=72$ vibracorder recordings. occurs during the night. Our observations of livestock grazing patterns were very similar to previous work (Gillen et al. 1984, Howery et al. 1996, Porath et al. 2002). These researchers used the same or similar study sites and grazing seasons as our research.

The season of use $\mathrm{x}$ time of day interaction was important $(\mathrm{P}<0.05)$ for cattle use of various vegetation types (Fig. 6). In early summer, cattle spent the majority of their morning hours in upland vegetation types, gradually occupying riparian area vegetation types more frequently as the day progressed and hourly temperatures increased. During early summer, between the hours of 1230 until 1800 cattle spent nearly an equal proportion of time in upland and riparian vegetation types. Conversely, in late summer, cattle started out their day in upland vegetation types but rapidly moved into riparian vegetation types after 0800 hours. They spent the remainder of the day in the riparian vegetation types, gradually returning to upland vegetation types during the late evening hours.

Over $90 \%$ of the cow observations during late summer were in riparian areas from 1200 to 1700 hours. During early summer only 50 percent of observations were in riparian areas during the same time period (Fig. 6). Comparing the livestock observation data (Fig. 6) with the vibracorder data (Fig. 5) peak late summer mid-day grazing occurred from 1200 to 1400 hours, which was also the time of highest riparian area occupancy in late summer (Fig. 3). These data illustrate the potential for increased riparian vegetation utilization by cattle during the heat of the day in late summer.

\section{Vegetation Utilization and Stubble Height}

Vegetation utilization patterns differed between years (Table 1). During the 1998 early grazing season utilization levels in riparian and upland vegetation types averaged $31 \%$ and $37 \%$ use, respectively. Late summer utilization levels in riparian vegetation and upland vegetation averaged $42 \%$ and $34 \%$ use, respectively (Table 1 ). During the 1999 early grazing season utilization levels in riparian and upland vegetation types averaged $41 \%$ and $40 \%$ use, respectively. However, during the late summer grazing season riparian vegetation utilization was disproportionately higher $55 \%$ than upland vegetation utilization $34 \%$. Thus, early summer grazing resulted in nearly equal utilization of upland and riparian vegetation types both years of the 


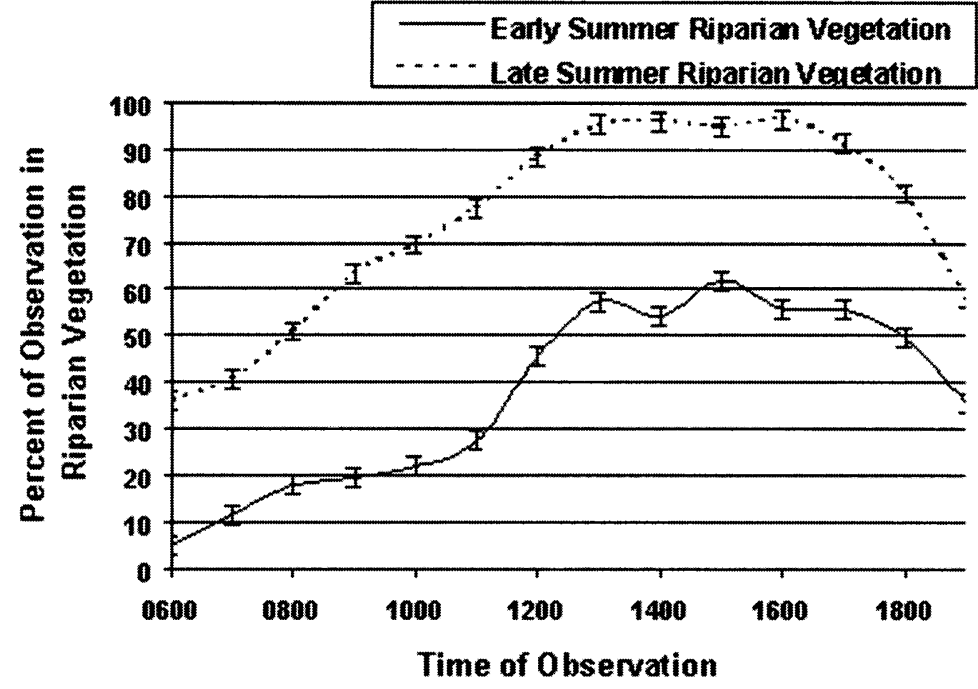

Fig. 6. Percent of livestock observations within riparian vegetation during early and late summer. Values are averaged over 1998 and 1999. All values within a time period differ at $p<$ 0.05. Bars indicate the standard errors. $N=23,744$ total observations.

study. This uniform use likely reflects more uniform livestock distribution during the early summer grazing period. During the late summer grazing period, the green line vegetation approached $60 \%$ use, compared to only $36 \%$ use during the early summer (Table 1), once again showing the increased potential for riparian area degradation in late summer.

Stubble height measurements differed between years $(P=0.04)$ and between seasons of use $(P=0.01)$, except for green line and gravel bar vegetation types $(\mathrm{P}=$ $0.75)$, but did not exhibit a season of use $x$ year interaction $(P=0.81)$, except for riparian grass $(P=0.01)$. Post grazing stubble height measurements closely followed our vegetation utilization estimates with increasing vegetation utilization resulting in decreased stubble height. However, the magnitude of difference was less with the stubble height measurements, possibly due to the differing plant phenologies associated with early summer and late summer grazing seasons.

\section{Forage Nutrient Composition and Quantity}

Nutrient composition of available forage varied $(\mathrm{P}<0.01$; Table 2$)$ between seasons of use with early summer forage having lower DM and fiber (ADF, NDF and lignin), and increased CP, and ISDMD compared with late summer forage. However, there was no difference $(\mathrm{P}>$ $0.05)$ between upland and riparian area forage composition within seasons. The lack of a difference in forage composition between upland and riparian vegetation types could be due to random sampling. Free-ranging ungulates are more selective than can be simulated with randomly clipped samples (Van Dyne et al. 1980). The lack of a difference in forage composition does not preclude the potential for differences in actual cattle diets selected in riparian versus upland vegetation types.

As the grazing season progressed, ambient air temperatures increased and the herbaceous vegetation matured and senesced, leading to a decrease in forage quality and an increase in forage DM content. Past research has shown that vegetation quality and quantity play significant roles in determining distribution patterns of cattle. Marlow and Pogacnik (1986) reported differences in livestock distribution patterns due to physiological stage of vegetation, while Owens et al. (1991) listed grass quantity as a major influence of vegetation utilization. Forage quantity was similar $(P=0.7$; Table 2$)$ during early and late summer grazing seasons. Riparian areas had greater forage standing crop ( $P$ $<0.05)$ than uplands regardless of season (Table 2).

Water intake of a given class of cattle in a specific management regime is a function of dry matter intake and ambient air temperature (NRC 1996). Early summer ambient air temperatures averaged $16.4^{\circ} \mathrm{C}$ while late summer temperatures averaged $21.4^{\circ} \mathrm{C}$. At these temperatures, a $450-\mathrm{kg}$ lactating beef cow requires 55 and 64 liters of water daily in the early and late summer, respectively (NRC 1996). Assuming $2.5 \%$ of body weight intake and $40 \%$ forage DM (early summer), a $450-\mathrm{kg}$ cow will consume $28-\mathrm{kg}$ of forage. Of this $28-\mathrm{kg}, 15.7-\mathrm{kg}$ is water, providing 16.5 liters of required water day ${ }^{-1}$, leaving 38.5 liters needed to meet the cow's daily water

Table 1. Influence of season of use on utilization and stubble height of upland and riparian vegetation measured immediately after cattle grazing during 1) early summer (mid-June to mid-July), and 2) late summer (mid-August to mid-September).

\begin{tabular}{|c|c|c|c|c|c|c|c|c|c|}
\hline \multirow[b]{2}{*}{ Utilization (\%) } & \multirow[b]{2}{*}{ Vegetation Type } & \multicolumn{2}{|c|}{1998} & \multicolumn{2}{|c|}{1999} & \multirow[b]{2}{*}{$\mathrm{SE}^{1}$} & \multicolumn{3}{|c|}{ P-values } \\
\hline & & Early & Late & Early & Late & & Year & Season & Season $\mathrm{x}$ Year \\
\hline \multirow[t]{4}{*}{ Riparian Vegetation } & Green Line & 28 & 57 & 44 & 62 & 3.8 & .01 & .01 & .05 \\
\hline & Gravel Bar & 36 & 29 & 43 & 62 & 4.9 & .01 & .29 & .01 \\
\hline & Grass & 37 & 42 & 44 & 52 & 1.9 & .01 & .01 & .16 \\
\hline & Sedge/Rush & 22 & 38 & 33 & 44 & 2.5 & .01 & .01 & .29 \\
\hline \multirow[t]{2}{*}{ Upland Vegetation } & Open & 43 & 36 & 44 & 38 & 0.8 & .02 & .01 & .54 \\
\hline & Covered & 32 & 31 & 35 & 30 & 1.0 & .12 & .01 & .03 \\
\hline \multirow{2}{*}{\multicolumn{10}{|c|}{$\begin{array}{l}\text { Stubble Height }(\mathrm{cm}) \\
\text { Vegetation Type }\end{array}$}} \\
\hline & & & & & & & & & \\
\hline \multirow[t]{4}{*}{ Riparian Vegetation } & Green Line & 14 & 12 & 11 & 9 & 1.5 & .04 & .21 & .81 \\
\hline & Gravel Bar & 13 & 10 & 10 & 7 & 1.6 & .01 & .75 & .09 \\
\hline & Grass & 15 & 21 & 10 & 9 & 0.7 & .01 & .01 & .01 \\
\hline & Sedge/Rush & 33 & 26 & 21 & 17 & 2.1 & .01 & .01 & .44 \\
\hline \multirow[t]{2}{*}{ Upland Vegetation } & Open & 13 & 16 & 11 & 14 & 0.4 & .01 & .01 & .49 \\
\hline & Covered & 18 & 21 & 13 & 16 & 0.5 & .01 & .01 & .77 \\
\hline
\end{tabular}

${ }^{1} \mathrm{SE}=$ standard error $(\mathrm{n}=4,648$ total ocular utilization estimates $)$. 
Table 2. Effects of season of use and pasture vegetation classification on nutrient composition and quantity of forage averaged across 1998 and 1999.

\begin{tabular}{|c|c|c|c|c|c|c|c|c|}
\hline \multirow[b]{2}{*}{ Item } & \multicolumn{2}{|c|}{ Early Summer } & \multicolumn{2}{|c|}{ Late Summer } & \multirow[b]{2}{*}{$\mathrm{SE}^{4}$} & \multicolumn{3}{|c|}{ P-values } \\
\hline & Riparian & Upland & Riparian & Upland & & Season & Vegetation & Season $\mathrm{x}$ Vegetation \\
\hline Dry Matter \% & 42.9 & 40.7 & 68.2 & 70.3 & 3.57 & .01 & .97 & 56 \\
\hline Neutral Detergent Fiber \% & 61.9 & 61.4 & 68.4 & 67.1 & 1.01 & .01 & .39 & .74 \\
\hline Acid Detergent Fiber $\%$ & 32.7 & 34.0 & 38.8 & 37.4 & 0.73 & .01 & .96 & .11 \\
\hline Crude Protein \% & 8.2 & 7.4 & 4.5 & 4.2 & 0.22 & .01 & .06 & .28 \\
\hline Lignin $\%^{5}$ & 4.2 & 5.9 & 7.1 & 6.5 & 0.65 & .04 & .44 & .13 \\
\hline ISDMD $\%{ }^{1}$ & 49.1 & 50.4 & 42.4 & 42.9 & 0.85 & .01 & .35 & .65 \\
\hline ISNDFD $\%^{2}$ & 28.3 & 29.9 & 25.9 & 25.8 & 0.68 & .01 & .27 & .25 \\
\hline Forage Quantity ${ }^{3}(\mathrm{~kg} / \mathrm{ha})$ & 1654 & 972 & 1726 & 1065 & 239 & .74 & .03 & .97 \\
\hline
\end{tabular}

Treatment= early summer (mid-June to mid-July), and late summer (mid-August to mid-September). Vegetation = vegetation site (riparian or upland). ${ }^{1}$ ISDMD = In situ dry matter disappearance. ${ }^{2}$ ISNDFD $=$ In situ neutral detergent fiber disappearance.

${ }^{3}$ Forage Quantity $=$ random clipped plots mid way through grazing season $(\mathrm{kg} / \mathrm{ha}) .{ }^{4} \mathrm{SE}=$ standard error $(\mathrm{n}=240$ total clipped plots).

requirement. During late summer grazing with increased ambient air temperatures and increased forage DM, the same 450$\mathrm{kg}$ lactating beef cow requires 64 liters of water (NRC 1996) and, due to higher forage DM $(70 \%)$, the forage is providing only 4.7 liters, leaving 59.3 liters of water she must obtain from the stream or offstream water sources. Therefore, cattle must utilize the stream for most of their daily-required water during late summer grazing. Additionally, declining forage quality during late summer can increase the amount of heat produced from microbial fermentation in the rumen, which may increase dependence on water for thermoregulation (NRC 1981).

\section{Fecal Deposits}

Fresh fecal deposits within 1-m of the stream were similar $(P=0.13)$ averaging 13 early summer and 28 late summer (Fig. 7). Because fecal deposits within 1-m of the stream's edge can negatively impact water quality (Buckhouse and Gifford 1976) pastures grazed in late summer may have a higher potential of negatively impacting water quality than pastures grazed early summer. However, this may only be true if a high intensity rainstorm is experienced during grazing or up to 1 month post-grazing (Buckhouse and Gifford 1976).

\section{Precipitation}

The dramatic difference in annual precipitation could have a major impact on forage quality and quantity and possibly affect livestock distribution and vegetation utilization patterns. Timing of precipitation can also impact forage quality and quantity.

\section{Management Implications}

Early summer grazing of riparian areas altered cow-calf grazing distribution and forage utilization patterns in the foothill rangelands of the Wallowa Mountains compared to late summer grazing. During early summer, when forage quantity and quality were not limiting and ambient air temperatures were low, livestock distribu-

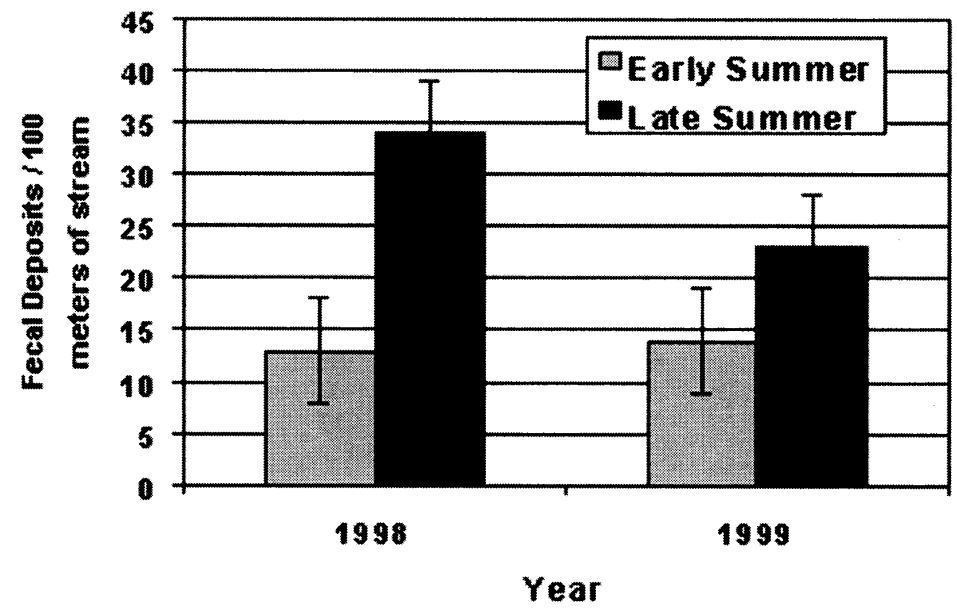

Fig. 7. Number of fresh fecal deposits within 1-m of stream in pastures grazed during early and late summer. Data did not differ within years $(P=0.13)$. Bars indicate standard errors. $N=673$ total fecal deposits.

tion patterns were more evenly distributed and vegetation utilization patterns more uniform. During late summer, ambient air temperatures and forage DM increased, and livestock distance from the stream decreased. Early summer grazing of riparian areas may be less detrimental to riparian areas because of improved livestock distribution and more uniform vegetation use. Furthermore, by grazing the riparian areas early a manager is providing the potential for riparian vegetation regrowth (Elmore and Kauffman, 1994). During late summer grazing, management practices such as offstream water developments, herding cattle out of riparian areas during the heat of the day, and providing alternative shade sources may achieve more uniform cattle distribution and vegetation utilization patterns.

While these are potential management alternatives, managers must remain aware of the forces in a particular system that are driving livestock distribution patterns in a particular system and implement decisions accordingly. Rangelands and riparian areas are dynamic systems and are constantly changing, thus making management decisions a daily activity. This variability necessitates the need for adaptive management and monitoring aimed at meeting a variety of goals (e.g., environmental, ranch, and economic). Continued, focused research is needed to obtain a better understanding of the interactions between grazing animals and rangeland systems.

\section{Literature Cited}

AOAC. 1990. Official Methods of Analysis (15th Ed.), Association of Official Analytical Chemists. Washington D.C. 
Buckhouse, J.C. and G.F. Gifford. 1976 Water quality implications of cattle grazing on a semiarid watershed in southeastern Utah. J. Range Manage. 29:109-113.

Elmore, W. and J.B. Kauffman. 1994. Riparian and watershed systems: Degradation and restoration. In: Ecological implications of livestock herbivory in the West. Edited by Martin Vavra, William A Laycock, and Rex D. Piper. Soc. for Range Manage., Denver, Colo. pp 212-231.

Frost, W.E., E.L. Smith, and P.R. Ogden. 1994. Utilization guidelines. Rangelands 16:256-259.

Gillen, R.L., W.C. Krueger, and R.F. Miller. 1984. Cattle distribution on mountain rangeland in northeastern Oregon. J. Range Manage. 37(6):549-553.

Gillen, R.L., W.C. Krueger, and R.F. Miller. 1985. Cattle use of riparian meadows in the Blue Mountains of northeastern Oregon. J. Range Manage. 38(3):205-209.

Howery, L.D., F.D. Provenza, R.E. Banner, and C.B. Scott. 1996. Differences in home range habitat use among individuals in a cattle herd. Appl. Anim. Behav. Sci. 49:305-320.

Komarek, A.R. 1993. A filter bag procedure for improved efficiency of fiber analysis. J. Dairy Sci. 76 (suppl 1) :250 (Abstr.).

Komarek, A.R. and P.K. Sirios. 1993. Improved effeciency of ADF analysis using a filter bag procedure. J. Anim. Sci. 71 (suppl 1) :284 (Abstr.).
Leonard, S., G. Kinch, V. Elsbernd, M. Borman, and S. Swanson. 1997. Riparian area Management: grazing management for riparian-wetland areas. USDI BLM. Denver, Colo.

Marlow, C.B., and T.M. Pogacnik. 1986. Cattle feeding and resting patterns in a foothills riparian zone. J. Range Manage. 39:212--217.

Miner, J.R., J.C. Buckhouse, and J.A. Moore. 1992. Will a water trough reduce the amount of time hay-fed livestock spend in the stream (and therefore improve water quality)? Rangelands 14:35-38.

NRC. 1981. Effect of environment on nutrient requirements of domestic animals. Natioanal Academy Press. Washington D.C.

NRC. 1996. Nutritional Requirements of Beef Cattle, $7^{\text {th }}$ Ed., National Academy Press. Washington D.C.

Owens, K., K.L. Launchbauch, and J.W. Holloway. 1991. Pasture characteristics affecting spatial distribution of utilization by cattle in mixed brush communities. J. Range Manage. 44:118-123.

Pechanec, J.F. and F.D. Pickford. 1937. A weight estimate method for the determination of range or pasture production. J. Amer. Soc. Agron. 29:894-904

Porath M.L., P.A. Momont, T. DelCurto, N.R. Rimbey, J.A. Tanaka, and $M$. McInnis. 2002. Offstream water and salt as management strategies for improved cattle distribution and subsequent riparian health. $\mathbf{J}$. Anim. Sci. 80:346-356.
SAS. 1990. SAS User's Guide: Statistics. SAS Inst. Inc., Cary, N.C..

Sneva, F.A. 1969. Behavior of yearling cattle on eastern Oregon range. Oregon State Univ. Tech. Pap. No. 2624. Corvallis, Ore.

Thomas, J.W., C. Maser, and J.E. Fodek. 1979. Wildlife habitats in managed rangelands-the Great Basin of Southeastern Oregon. p. 1-18. In: Riparian Areas. USDA For. Ser. Gen. Tech. Rep. PNW-80.

USDI. 1995. Riparian-wetland initiative for the 1990's - annual report of accomplishments for fiscal year 1995. USDI, Bureau of Land Management. $43 \mathrm{p}$.

Van Dyne, G.M., N.R. Brockington, Z. Szocs, J. Duck and C.A. Ribic. 1980. Large herbivore systems. In: A.I. Breymeyer and G.M. Van Dyne (Ed.) Grasslands, Systems Analysis and Man. Cambridge Univ. Press. Cambridge, England.

Van Soest, P.J., J.B. Robertson, and B.A. Lewis. 1991. Methods for dietary fiber, neutral detergent fiber, and nonstarch polysaccharides in relation to animal nutrition. $\mathrm{J}$. Dairy Sci. 74:3583-3587. 